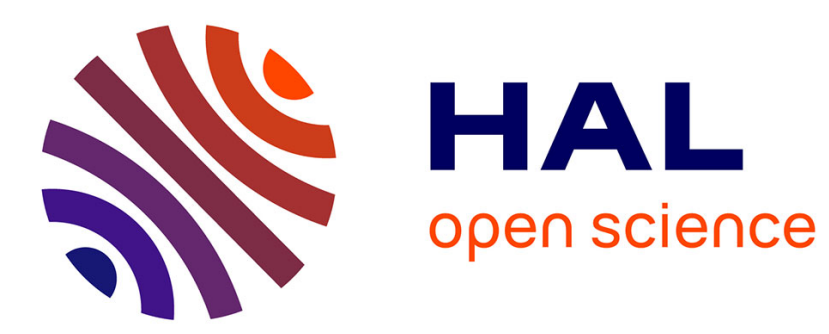

\title{
Fe K-EDGE X-RAY ABSORPTION SPECTROSCOPY OF SILICATE MINERALS AND GLASSES
}

\author{
N. Binsted, G. Greaves, C. Henderson
}

\section{To cite this version:}

N. Binsted, G. Greaves, C. Henderson. Fe K-EDGE X-RAY ABSORPTION SPECTROSCOPY OF SILICATE MINERALS AND GLASSES. Journal de Physique Colloques, 1986, 47 (C8), pp.C8-837C8-840. 10.1051/jphyscol:19868160 . jpa-00226064

\section{HAL Id: jpa-00226064 https://hal.science/jpa-00226064}

Submitted on 1 Jan 1986

HAL is a multi-disciplinary open access archive for the deposit and dissemination of scientific research documents, whether they are published or not. The documents may come from teaching and research institutions in France or abroad, or from public or private research centers.
L'archive ouverte pluridisciplinaire HAL, est destinée au dépôt et à la diffusion de documents scientifiques de niveau recherche, publiés ou non, émanant des établissements d'enseignement et de recherche français ou étrangers, des laboratoires publics ou privés. 
JOURNAL DE PHYSIQUE

Colloque $\mathrm{C} 8$, supplément au $\mathrm{n}^{\circ} 12$, Tome 47, décembre 1986

\title{
Fe K-EDGE X-RAY ABSORPTION SPECTROSCOPY OF SILICATE MINERALS AND GLASSES
}

\author{
N. BINSTED, G.N. GREAVES* and C.M.B. HENDERSON \\ Department of Geology, University of Manchester, \\ GB-Manchester M13 9PL, Great-Britain \\ "SERC Daresbury Laboratory, GB-Warrington WA4 4AD, \\ Great-Britain
}

\begin{abstract}
Abscract Structural parameters determined for crystalline iron, fayalite and aegirine agree closely with $X$-ray crystallographic data. A glass of $\mathrm{NaFeSi}_{2} \mathrm{O}_{6}$ composition has $\mathrm{Fe}$ predominantly present as $\mathrm{Fe}^{3+}$ in tetrahedral coordination i.e. as a network former. $\mathrm{CaFeSiO}_{4}$ and $\mathrm{CaFeSi}_{2} \mathrm{O}_{6}$ glasses have about $\frac{1}{3}$ of the total $\mathrm{Fe}$ in octahedral coordination i.e. as a network modifier.
\end{abstract}

Introduction An understanding of the structural role of iron in silicate melts is important not only in explaining rheological and diffusion properties and phase relations, but also because of the significance of redox ratios as oxygen fugacity indicators. As part of an ongoing study of the application of synchrotron techniques to geological problems we have, therefore, investigated silicate minerals and glasses by Fe K-edge X-ray absorption spectroscopy. Spectra were recorded in transmission at the SRS using a harmonic rejecting double crystal monochromator (Si 220).

Crystalline body-centred metallic iron, fayalite $\left(\mathrm{Fe}_{2} \mathrm{Si}_{4}\right.$ ) and aegirine $\left(\mathrm{NaFeSi}_{2} \mathrm{O}_{6}\right)$ were used as model compounds for $\mathrm{Fe}$ as $\mathrm{Fe}^{\circ}, \mathrm{Fe}^{2+}$ and $\mathrm{Fe}^{3+}$, respectively. Background subtracted, $\mathrm{k}^{3}$ weighted spectra were analysed using the Daresbury Library Program EXCURVE which utilises spherical wave theory and least squares routines [1]. Glasses having the compositions of aegirine, hedenbergite $\left(\mathrm{CaFeSi}_{2} \mathrm{O}_{6}\right)$ and kirschsteinite $\left(\mathrm{CaFeSiO}_{4}\right)$ were prepared by quenching me1ts produced under atmospheric conditions at $1300^{\circ} \mathrm{C}$. Microprobe analyses showed these to be homogeneous and oncomposition while chemical analyses gave $\mathrm{Fe}^{3+} / \Sigma \mathrm{Fe}$ ratios of $0.9,0.8$ and $0.9( \pm 0.03)$, respectively.

Results The absorbance spectra for the samples studied are figured in an earlier progress report [2]. The derivative of the absorbance is shown here (figure 1) allowing the energies of the absorption edge and associated features to be deduced to an accuracy of $\pm 0.5 \mathrm{eV}$. As expected, the model compounds show an increase in the edge energy with increasing oxidation state of $\mathrm{Fe}$, from $7115 \mathrm{eV}$ (iron $\mathrm{Fe}^{\circ}$, fig. la) through $7123 \mathrm{eV}$ (fayalite, $\mathrm{Fe}^{2+}, \mathrm{b}$ ) to $7128 \mathrm{eV}$ (aegirine, $\mathrm{Fe}^{3+}, \mathrm{c}$ ). Weak pre-edge features occur in both fayalite and aegirine due to $1 \mathrm{~s} \rightarrow 3 \mathrm{~d}$ transitions enhanced by hybridization of iron 3d with oxygen $2 p$ orbitals [4]. This feature should increase in intensity in the order: regular octahedral-distorted octahedral-tetrahedral coordination. The pre-edge feature occurs at $7114 \mathrm{eV}$ in fayalite and $7116 \mathrm{eV}$ in aegirine confirming the $2 \mathrm{eV}$ shift previously reported for $\mathrm{Fe}^{2+}$ and $\mathrm{Fe}^{3+}$ [3].

Figure 2 shows background subtracted EXAFS (as measured), Fourier filtered spectra, and the Fourier transform of the spectra. Dotted lines refer to the best curved wave fit to experiment: comparison is made with respect to Fourier filtered spectra for clarity. A11 the model compounds show excellent agreement between the EXAFS and crystallographic data $( \pm 0.02 \AA$ for first shell distances). Mean Fe-0 
distances of $2.22 \AA$ and $2.03 \AA$ for fayalite and aegirine are consistent with the presence of octahedrally coordinated $\mathrm{Fe}^{2+}$ and $\mathrm{Fe}^{3+}$, respectively. The EXAFS data also reproduce the distorted nature of the oxygen ligands in both minerals. The asymmetry of the $\mathrm{Fe}$ sites is also responsible for the smal1 pre-edge feature around $7115 \mathrm{eV}$.

The three glasses have spectra with less XANES structure above the edge compared with the crystalline silicates; this is consistent with decreased long-range order in the glasses. For each of the three glasses the absorption edge threshold occurs at $7127 \mathrm{eV}$ consistent with the bulk of the Fe existing as $\mathrm{Fe}^{3+}$. In addition, all the glasses have more-pronounced pre-edge features than those shown for the crystalline materials (fig. 1). This is particularly true for aegirine glass (NaFeSi ${ }_{2} 0_{6}$ ) which exhibits the strongest pre-edge feature pointing to tetrahedrally coordinated $\mathrm{Fe}$ sites. Analysis of the EXAFS spectra for the glasses (fig. 2e, $f, g)$ generates first shell Fe-0 distances of $1.86 \AA$ for $\mathrm{NaFeSi}_{2} \mathrm{O}_{6}$ and $1.92 \AA$ for $\mathrm{CaFeSi}_{2} \mathrm{O}_{6}$ and $\mathrm{CaFeSiO}_{4}$ compositions composed to $2.03 \AA$ for crysta 11 ine NaFeSi $\mathrm{O}_{6}$. The shorter average $\mathrm{Fe}-0$ distance for $\mathrm{NaFeSi}_{2} \mathrm{O}_{6}$ glass compared to crystalline aegirine (together with the narrower, more intense Fourier transform peak for the glass, fig. 2c,d) confirms that $\mathrm{Fe}^{3+}$ is almost certainly tetrahedrally coordinated

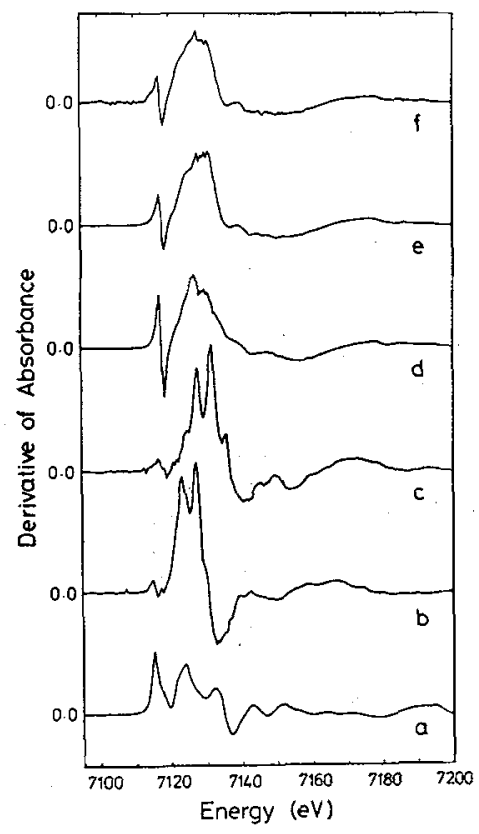

Figure 1. Derivative of absorbance for Fe EXAFS spectra. a = Fe metal; $b=$ fayalite crystal; $c=$ aegirine crystal; $d=\mathrm{NaFeSi}_{2} \mathrm{O}_{6}$ glass; $e=$ $\mathrm{CaFeSiO}_{4}$ glass; $f=\mathrm{CaFeSi}_{2} \mathrm{O}_{6}$ glass in the glass. In contrast, the slightiy longer Fe-0 distances in the Ca-bearing glasses suggest that up to $\frac{1}{3}$ of the of the $\mathrm{Fe}$ is present in octahedral coordination. These results confirm the observations of Mysen and his colleagues [e.g. 5,6] that, for samples prepared under oxidizing conditions, $\mathrm{Ca}-$ bearing glasses contain substantial amounts of $\mathrm{Fe}^{2+}$ while equivalent $\mathrm{Na}$-bearing glasses contajn $>95 \% \mathrm{Fe}^{3+}$. Moreover in both systems the $\mathrm{Fe}^{3+}$ present occurs predominantly in tetrahedral coordination.

Discussion The presence of $\mathrm{Fe}^{3+}$ in tetrahedral coordination in glasses quenched from silicate melts prepared under oxidizing conditions indicates that it acts as a network-former in both $\mathrm{Na}$ - and $\mathrm{Ca}$-bearing systems. In contrast, $\mathrm{Fe}^{2+}$ occurs in octahedral coordination i.e. as a network modifier. It has been suggested that tetrahedrally coordinated $\mathrm{Fe}^{3+}$ may not be randomly mixed with $\mathrm{Si}$ in framework units but instead may exist as discrete Fe-rich clusters $[6,7]$. If this is the case we might expect to resolve $\mathrm{Fe}-\mathrm{Fe}$ interactions in the EXAFS spectra but we find no evidence of this phenomenon with glasses studied here.

Models for calculating viscosities and structural parameters such as the ratio non-bridging $0 /$ tetrahedral cations ( $\mathrm{NBO} / \mathrm{T}$; $[8]$ ), depend on the correct assignment of $\mathrm{Fe}^{3+}$ to network-forming or -modifying roles.

P. Henderson et a1. [9] found a regular relationship between diffusion coefficients measured for a series of rock melts and conventionally-calculated NBO/T (i.e. $\mathrm{Fe}^{3+}$ as modifier). However data for a pantellerite melt (alkali-rich granite) fell off these trends. The pantellerite melt is relatively poor in $\mathrm{Al}$ and rich in $\mathrm{Fe}^{3+}\left(\mathrm{Fe}^{3+} /\right.$ $\Sigma \mathrm{Fe} 0.82)$ and it seems likely that much of the $\mathrm{Fe}^{3+}$ would be acting as a tetrahedral network former. Recalculation of NBO/T on this basis brings the pantellerite melt into line with the others for $\mathrm{Ba}$, Eu and Fe diffusion. 

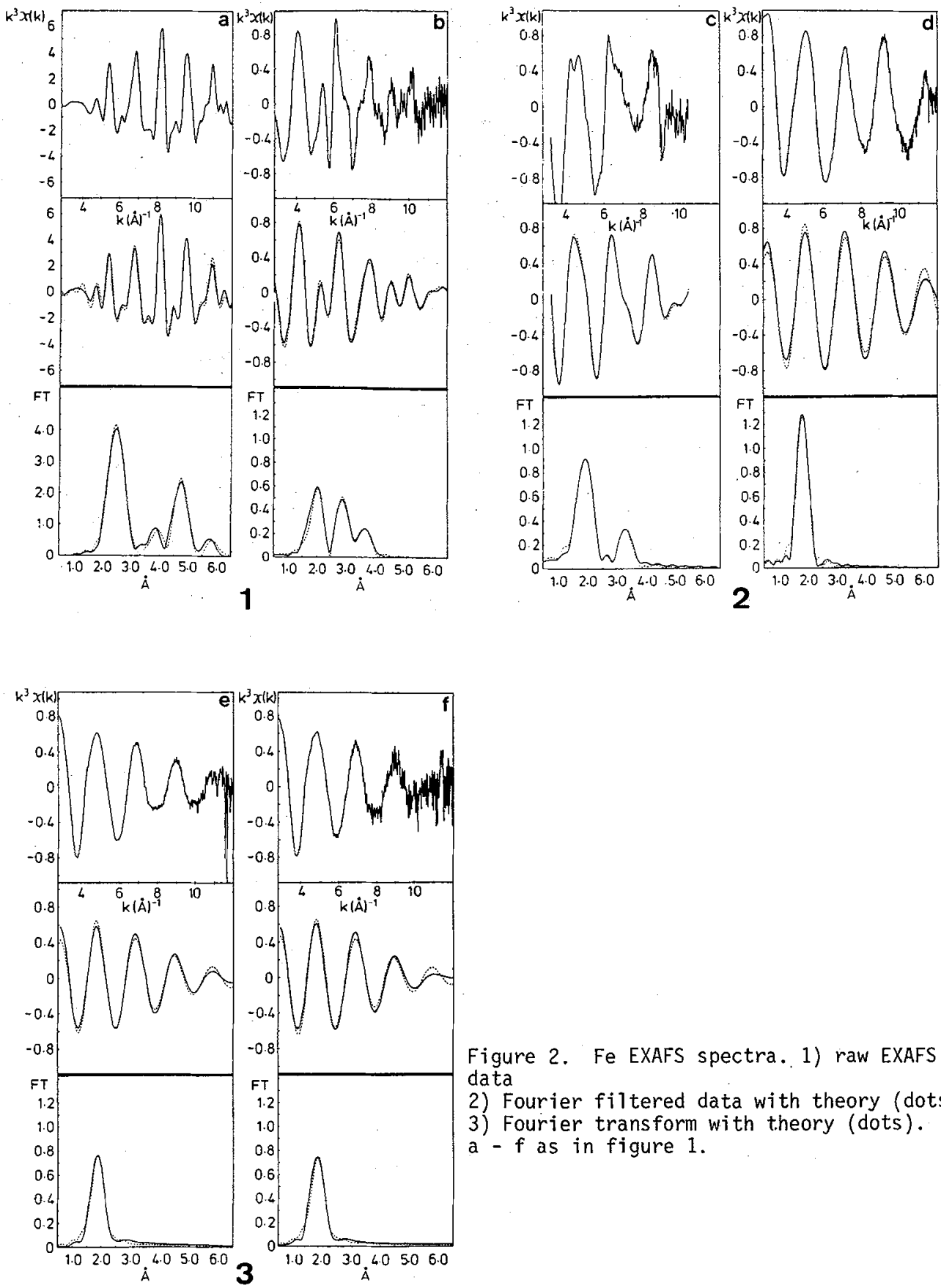

Figure 2. Fe EXAFS spectra. 1) raw EXAFS data

2) Fourier filtered data with theory (dots) 3) Fourier transform with theory (dots). a - $f$ as in figure 1. 


\section{References}

[1] Gurman, S.J., Binsted, N., and Ross, I. J. Phys., C17, 143 (1984).

[2] Binsted, N., Greaves, G.N., and Henderson, C.M.B. Progr. Expt. Petrology (N.E.R.C.), 6, 59 (1984).

[3] Waychunas, G.A., Apted, M.J., and Brown, G.E. Phys. Chem. Minerals, 10, 1 (1983).

[4] Calas, G. and Petiau, J. Structure of non-crystalline materials (Second Int. Conf.), 18 (1982).

[5] Mysen, B.0., Seifert, F., and Virgo, D. Am. Mineral., 65, 867 (1980).

[6] Virgo, D. and Mysen, B.0. Phys. Chem. Minera1s, 12, 65 (1985).

[7] Virgo, D., Mysen, B.0., Danckwerth, P., and Seifert, F. Carnegie Inst., Washington Yearbook, 81, 349 (1982).

[8] Mysen, B.0., Virgo, D. and Kushiro, I. Amer. Minera1., 66, 678 (1981).

[9] Henderson, P., Nolan, J., Cunningham, G.C., and Lowry, R.K. Contrib. Min. Petr., 89, 263 (1985). 